\title{
Nursing care related to fall prevention among hospitalized elderly people: an integrative review
}

\section{Cuidados de enfermagem relacionados à prevenção do risco de quedas de idosos hospitalizados: revisão integrativa}

Atención de enfermería relacionada con la prevención del riesgo de caídas en ancianos hospitalizados: una revisión integradora

Adnairdes Cabral de Sena' ORCID: 0000-0002-8926-4904

Angela Maria Alvarez' ORCID: 0000-0002-2622-3494

Simony Fabíola Lopes Nunes' ORCID: 0000-0003-4613-8542

Nadia Pinheiro da Costa' ORCID: 0000-0001-6550-366X

'Universidade Federal de Santa Catarina. Florianópolis, Santa Catarina, Brazil.

How to cite this article: Sena AC, Alvarez AM, Nunes SFL, Costa NPS. Nursing care related to fall prevention among hospitalized elderly people: an integrative review. Rev Bras Enferm. 2021;74(Suppl 2):e20200904. https://doi.org/10.1590/0034-7167-2020-0904

Corresponding author: Adnairdes Cabral de Sena adnairdes-13@hotmail.com

EDITOR IN CHIEF: Antonio José de Almeida Filho ASSOCIATE EDITOR: Maria Isabel Salamanca

Submission: 08-28-2020

Approval: 12-21-2020

\section{ABSTRACT}

Objective: to identify scientific productions on nursing care related to fall risk prevention among hospitalized elderly people. Methods: an integrative literature review from 2015 to 2019 in the PubMed/MEDLINE, Scopus, Web of Science, LILACS, BDENF, SciELO and CINAHL databases, in Portuguese, English and Spanish. The keywords were elderly, hospitalization, accidents due to falls, nursing care. Results: thirty-three publications were analyzed. The synthesis of the studies resulted in the categories: Clinical nursing assessments to prevent falls among hospitalized elderly people; Fall risk factors for elderly people; Fall risk prevention strategies for elderly people. Final considerations: it was found that the scientific knowledge produced on nursing care related to fall risk prevention for hospitalized elderly people evidences the clinical assessment, risk factors and strategies such as nursing care, contributing to foster self-care behavior and promotion security for elderly people.

Descriptors: Aged; Hospitalization; Accidental Falls; Nursing Care; Review.

\section{RESUMO}

Objetivo: identificar produções científicas sobre os cuidados de enfermagem relacionados à prevenção do risco de quedas de idosos hospitalizados. Métodos: revisão integrativa da literatura de 2015 a 2019 nas bases de dados PubMed/MEDLINE, Scopus, Web of Science, LILACS, BDENF, SciELO e CINAHL, em português, inglês e espanhol. As palavras-chave foram idoso, hospitalização, acidentes por quedas, cuidados de enfermagem. Resultados: foram analisadas 33 publicações. A síntese dos estudos resultou nas categorias: Avaliações clínicas de enfermagem para prevenção de queda de idosos hospitalizados; Fatores de risco de queda de idosos; Estratégias de prevenção do risco de quedas de idosos. Considerações finais: constatou-se que os conhecimentos científicos, produzidos sobre os cuidados de enfermagem relacionados à prevenção do risco de quedas aos idosos hospitalizados, evidenciam a avaliação clínica, fatores de risco e estratégias como cuidados de enfermagem, contribuindo para estímulo ao comportamento de autocuidado da pessoa idosa e promoção de segurança ao idoso. Descritores: Idoso; Hospitalização; Acidentes por Quedas; Cuidados de Enfermagem; Revisão.

\section{RESUMEN}

Objetivo: identificar producciones científicas sobre cuidados de enfermería relacionadas con la prevención del riesgo de caídas en ancianos hospitalizados. Métodos: revisión integrativa de la literatura de 2015 a 2019 em PubMed/MEDLINE, Scopus, Web of Science, LILACS, BDENF, SciELO y CINAHL, en portugués, inglés y español. Las palabras clave fueron anciano, hospitalización, accidentes por caídas, cuidados de enfermería. Resultados: se analizaron 33 publicaciones. La síntesis de los estudios resultó en las categorías: Evaluaciones clínicas de enfermería para la prevención de caídas en ancianos hospitalizados; Factores de riesgo de caídas para los ancianos; Estrategias para prevenir el riesgo de caídas en ancianos. Consideraciones finales: el conocimiento científico, producido sobre cuidados de enfermería relacionados con la prevención del riesgo de caídas en ancianos hospitalizados, muestra la evaluación clínica, factores de riesgo y estrategias como el cuidado de enfermería, contribuyendo a estimular la conducta de autocuidado de los ancianos y promover seguridad.

Descriptores: Anciano; Hospitalización; Accidentes por Caídas; Atención de Enfermería; Revisión. 


\section{INTRODUCTION}

Falls occur when a body moves unintentionally to the ground. It is worth mentioning that hospitalization can increase fall risk, since the environments are not familiar and hospitalized people may have diseases or suffer multiple therapeutic interventions that may predispose to falls ${ }^{(1)}$. This situation, when it occurs, can cause stressful experiences for these people, representing moments of fragility, fear, suffering and the unpleasant feeling of insecurity before the disease ${ }^{(2)}$. Therefore, the prevention and management of fall risk for elderly people are directly linked to nursing care ${ }^{(3)}$.

To ensure the quality of care provided to patients, health services need to guarantee this service in a dignified environment, i.e., with an adequate structure and safe care practices linked to the principles and objectives of patient safety. Thus, nursing performs the care that is intrinsic to the profession, as these professionals remain 24 hours alongside patients ${ }^{(4)}$.

This service offered by nursing professionals is mediated by clinical practice that is based on care, guided by principles of evidence-based practice, enabling a systematic exercise capable of contributing to improving the quality of care provided ${ }^{(5)}$.

In this context, it is understood the importance of these professionals to carry out the assessment of risk factors for hospitalized elderly people since their admission, with the implementation of prevention strategies, providing security to this elderly clientele during their stay in the hospital environment ${ }^{(6)}$. Nursing care for elderly people must be effective and timely to ensure fall prevention ${ }^{(7)}$.

It is noteworthy that gerontological nursing directs care from prevention, rehabilitation to maintaining elderly people' well-being and quality of life. Therefore, during hospitalization, it is important that care is directed and makes it possible to identify the risk factors related to the fall event. Hospitalized elderly people may have limitations in their functional capacity, making them predisposed and susceptible to the occurrence of falls, worsening their clinical condition.

Thus, it becomes essential to identify nursing care practices for fall risk prevention for this population during the hospitalization period. The question that guided this review was: what are the scientific productions available in the databases consulted about nursing care related to fall risk prevention among hospitalized elderly people?

\section{OBJECTIVE}

To identify scientific productions on nursing care related to fall risk prevention among hospitalized elderly people.

\section{METHODS}

\section{Type of study}

The integrative literature review (ILR) is a methodological approach that synthesizes the studies done on the respective theme, allowing the inclusion of experimental and non-experimental investigations ${ }^{(8)}$ with a qualitative approach. In this study, seven steps were followed: elaboration of the guiding question; review purpose formulation; establishment of eligibility criteria; previous reading to select the articles that made up the review corpus; analysis of all articles included in the review; discussion of results; synthesis presentation ${ }^{(9)}$.

\section{Problem identification}

For the research problem, the question was raised: what are the scientific productions available in the databases on nursing care related to fall risk prevention in hospitalized elderly people?

\section{Literature search}

The search was carried out at the Virtual Health Library (VHL), which includes the databases: Latin American and Caribbean Literature in Health Sciences (LILACS) and Nursing Database (BDENF), Scientific Electronic Library Online (SCIELO). The CAPES journals portal and the PubMed, U.S. National Library of Medicine, Medical Literature Analysis and System Online (MEDLINE), Web of Science, Scopus and Cumulative Index of Nursing and Allied Health Literature (CINAHL) databases were also consulted.

The following controlled descriptors, keywords, synonyms and Boolean operators were used for the crossing, considering the particularities of each database:

- PubMed, U.S. National Library of Medicine, Web of Science, Scopus, and CINAHL: ("Aged" OR "elderly" OR "older" OR "aged person" OR "aged persons" OR "aged people" OR "aged adult" OR "aged adults" OR "aged population" OR "old age" OR "old aged" OR "older age" OR "third age" OR "Aging" OR "Senescence" OR "Adults Aged"OR"older adult" OR "elderly people") AND ("Hospitalization" OR "Hospitalizations" OR "internment" OR "Inpatients" OR "Inpatient") AND ("Accidental Falls"OR"falls"OR"Falling"OR"Accidental Fall" OR "Slip and Fall" OR "Fall and Slip") AND ("Accident Prevention"OR "Accident Preventions" OR "Prevention" OR "Preventive measures")

- BDENF, LILACS, and SCIELO: ("Aged" OR "elderly" OR "older" OR "aged person" OR "aged persons" OR "aged people" OR "aged adult" OR"aged adults" OR"aged population" OR "old age" OR "old aged" OR "older age" OR "third age" OR "Aging" OR "Senescence" OR "Adults Aged" OR "older adult" OR "elderly people" OR "Idoso" OR "Idosos" OR "Pessoa Idosa" OR "Pessoas Idosas"OR"Pessoa de Idade"OR"Pessoas de Idade" OR "População Idosa" OR "ancião" OR "anciões" OR "terceira idade" OR "Envelhecimento" OR "senescência" OR "senência" OR "Anciano" OR "Ancianos" OR "Persona de edad" OR "Personas de edad"OR"Población Ancianos"OR"Población Anciana"OR"elder"OR"tercera edad") AND ("Hospitalization" OR "Hospitalizations" OR "internment" OR "Inpatients" OR "Inpatient" OR "Hospitalização" OR "Internação Hospitalar" OR "Internamento" OR "Internação" OR hospitaliza* OR "Pacientes Internados"OR"Paciente Internado"OR"Paciente" $O R$ "Pacientes"OR"Hospitalización"OR"Internación Hospitalaria" OR "Internación" OR "Pacientes Internos") AND ("Accidental Falls" OR "falls" OR "Falling" OR "Accidental Fall" OR "Slip and Fall"OR"Fall and Slip"OR"Acidentes por quedas"OR"Acidente 
por queda"OR"queda"OR"quedas"OR"Accidentes por Caídas" OR"Accidente por Caída"OR"caída"OR"caídas") AND ("Accident Prevention"OR "Accident Preventions" OR "Prevention" OR "Preventive measures" OR "Prevenção de Acidentes" OR "Prevenção" OR "Medidas preventivas" OR "Prevención de Accidentes" OR "Prevención")).

Data collection was performed by four reviewers from February to April 2020. Online texts, complete and published between 2015 and 2019 in scientific journals available on the cited databases that addressed nursing care for the fall risk prevention of hospitalized elderly people were included; editorials, letters, reviews, reports of experiences, summaries in annals of events, expanded abstracts, studies published in languages other than Brazilian Portuguese, English and Spanish were excluded. Articles in which participants were not elderly in the hospital environment or research with a heterogeneous sample were also excluded (e.g., adults and elderly people).

\section{Selection process}

The selection process for titles and abstracts was carried out independently by two authors based on the inclusion and exclusion criteria. They proceeded with reading, evaluating and selecting the full articles. In these steps, doubts about the inclusion of studies were resolved in a consensus meeting with a third researcher.

In the end, a consensus was reached that 33 publications would be considered for reading the full text and would have the following information extracted: name of the authors, year of publication, country, design, objective, main results and thematic content addressed about the fall phenomenon in hospitalized elderly people.

\section{Data analysis}

The data analysis process came from the results found, being organized in a descriptive way, with the synthesis of each article, establishing the relevant points attending the nursing care related to fall risk prevention with hospitalized elderly people; three thematic categories were formed.

\section{RESULTS}

Thus, 1,722 studies published between 2015 and 2019 were found. However, repeated articles were identified, 494 of which were excluded at this stage. Thus, after solving the duplications, 1,228 articles were selected to read the titles and abstracts; at this stage, 991 publications were excluded when the inclusion criteria were applied. After reading in full the 237 selected articles, it was found that: seven articles were about children; 30 dealt with adults; 100 articles had only the abstract available; 50 treated elderly people, but not in the hospital environment; 17 studies included not only elderly people, but also adults. Thus, 33 studies for analysis were included in the review. Figure 1 illustrates the study selection process and reveals the reasons for exclusion.

According to the eligibility criteria, 33 articles published between 2015 and 2019 were selected. The characteristics of studies are shown in Chart 1.

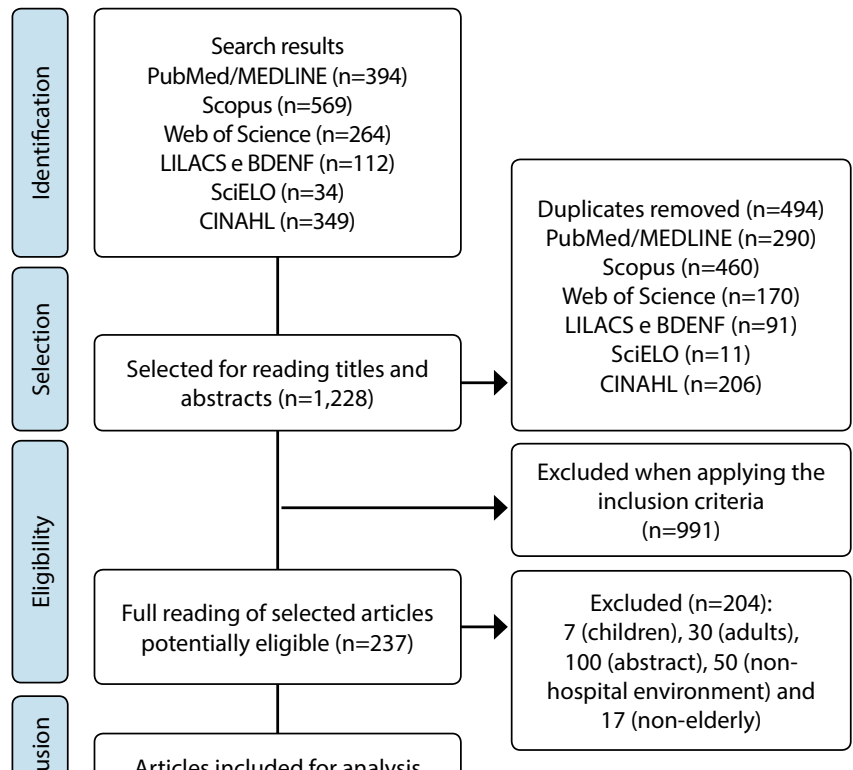
review $(n=33)$

Figure 1 - Flowchart of selection and inclusion of studies in the review

Chart 1 - Characterization of articles published between 2015 and 2019 selected for integrative literature review, Florianópolis, Santa Catarina, Brazil, 2020

\begin{tabular}{|c|c|c|c|c|}
\hline $\begin{array}{l}\text { Authors year/ } \\
\text { country }\end{array}$ & Design & Objective & Main results & Thematic content \\
\hline $\begin{array}{l}\text { Royset et al. } \\
2019^{(10)} \\
\text { Norway }\end{array}$ & $\begin{array}{l}\text { Quantitative study } \\
\mathrm{n}=3,143\end{array}$ & $\begin{array}{l}\text { To assess the effects of fall } \\
\text { prevention program on reducing its } \\
\text { rate on patient safety culture. }\end{array}$ & $\begin{array}{l}\text { The fall prevention program showed no } \\
\text { significant effect on the rate of falls. }\end{array}$ & Fall risk factors. \\
\hline $\begin{array}{l}\text { Fridman } \\
2019^{(11)} \\
\text { United States of } \\
\text { America }\end{array}$ & Qualitative study & $\begin{array}{l}\text { To decrease falls and promote } \\
\text { patient safety, health and comfort. }\end{array}$ & $\begin{array}{l}\text { Current practices should be redesigned } \\
\text { to ensure that fall prevention and } \\
\text { acute care initiatives are consistent and } \\
\text { transformational. }\end{array}$ & $\begin{array}{l}\text { Clinical assessment and } \\
\text { fall prevention. }\end{array}$ \\
\hline $\begin{array}{l}\text { Yamashita } \\
\text { et al. } \\
2019^{(12)} \\
\text { Japan }\end{array}$ & $\begin{array}{l}\text { Quantitative study } \\
\mathrm{n}=180\end{array}$ & $\begin{array}{l}\text { To investigate changes in the } \\
\text { strength of the feet, knees and the } \\
\text { distribution of pressure in the feet. }\end{array}$ & $\begin{array}{l}\text { Care for feet and toenails can improve } \\
\text { lower limbs muscle strength, decrease fall } \\
\text { risk and distribute foot pressure. }\end{array}$ & Fall risk factors. \\
\hline
\end{tabular}


Chart 1

\begin{tabular}{|c|c|c|c|c|}
\hline $\begin{array}{l}\text { Authors year/ } \\
\text { country }\end{array}$ & Design & Objective & Main results & Thematic content \\
\hline $\begin{array}{l}\text { Bolton } \\
2019^{(13)} \\
\text { United States of } \\
\text { America }\end{array}$ & $\begin{array}{l}\text { Quantitative study } \\
\mathrm{n}=401\end{array}$ & $\begin{array}{l}\text { To determine the cost-effectiveness } \\
\text { of a hospital fall prevention program. }\end{array}$ & $\begin{array}{l}\text { At least } 4 \% \text { of cognitively intact patients } \\
\text { fell into the ward under the normal } \\
\text { conditions of care. }\end{array}$ & Fall risk factors. \\
\hline $\begin{array}{l}\text { Toye et al } \\
2019^{(14)} \\
\text { Australia }\end{array}$ & $\begin{array}{l}\text { Quantitative and } \\
\text { qualitative study } \\
\mathrm{n}=486\end{array}$ & $\begin{array}{l}\text { To investigate the association } \\
\text { between multiple movements and } \\
\text { bed falls during hospitalization of } \\
\text { elderly patients. }\end{array}$ & $\begin{array}{l}\text { Patients with high fall risk admitted to the } \\
\text { hospital are at increased risk of fall. }\end{array}$ & Fall risk factors. \\
\hline $\begin{array}{l}\text { Souza et al. } \\
2019^{(15)} \\
\text { Brazil }\end{array}$ & $\begin{array}{l}\text { Quantitative study } \\
\mathrm{n}=1,071\end{array}$ & $\begin{array}{l}\text { To describe in-hospital falls reported } \\
\text { in a large hospital in southern Brazil. }\end{array}$ & $\begin{array}{l}\text { Fall prevention strategies focus on } \\
\text { patients hospitalized patients in } \\
\text { hospitalization units aged } 60 \text { years or } \\
\text { older, assessed as high risk for falls. }\end{array}$ & $\begin{array}{l}\text { Fall prevention } \\
\text { strategies. }\end{array}$ \\
\hline $\begin{array}{l}\text { Ferreira et al. } \\
2019^{(16)} \\
\text { Brazil }\end{array}$ & Integrative review & $\begin{array}{l}\text { To identify the instruments for } \\
\text { evaluating the use of siderails in } \\
\text { hospitalized patients. }\end{array}$ & $\begin{array}{l}\text { Four articles using the same instrument, } \\
\text { Assessment of Siderail Use, were } \\
\text { selected, with a detailed approach to the } \\
\text { assessment of patients regarding the } \\
\text { use of siderails, discussing alternative } \\
\text { interventions for the use of siderails that } \\
\text { should be adapted to individual needs. }\end{array}$ & $\begin{array}{l}\text { Fall prevention } \\
\text { strategies. }\end{array}$ \\
\hline $\begin{array}{l}\text { Cunha et al. } \\
2019^{(17)} \\
\text { Portugal }\end{array}$ & $\begin{array}{l}\text { Quantitative- } \\
\text { qualitative study } \\
\mathrm{n}=18\end{array}$ & $\begin{array}{l}\text { To design and validate a team } \\
\text { intervention. }\end{array}$ & $\begin{array}{l}\text { It allowed to validate the intervention } \\
\text { of the team by panel of experts, so that } \\
\text { the teams can manage the fall risk in } \\
\text { hospitalized elderly patients. }\end{array}$ & Fall risk factors. \\
\hline $\begin{array}{l}\text { Wong and Pang } \\
2019^{(18)} \\
\text { China }\end{array}$ & $\begin{array}{l}\text { Quantitative study } \\
\mathrm{n}=123\end{array}$ & $\begin{array}{l}\text { To investigate factors associated with } \\
\text { falls in psychogeriatric patients. }\end{array}$ & $\begin{array}{l}\text { Patients with dementia and women had } \\
\text { higher fall risk. }\end{array}$ & $\begin{array}{l}\text { Fall prevention } \\
\text { strategies. }\end{array}$ \\
\hline $\begin{array}{l}\text { Dolan and Taylor- } \\
\text { Piliae } \\
2019^{(19)} \\
\text { United States of } \\
\text { America }\end{array}$ & $\begin{array}{l}\text { Theoretical reflection } \\
\text { study }\end{array}$ & $\begin{array}{l}\text { To describe the process of selecting a } \\
\text { theoretical framework. }\end{array}$ & $\begin{array}{l}\text { The Health Belief Model was selected as } \\
\text { the theoretical framework. }\end{array}$ & Fall risk factors. \\
\hline $\begin{array}{l}\text { Falcão et al. } \\
2019^{(20)} \\
\text { Brazil }\end{array}$ & $\begin{array}{l}\text { Quantitative study } \\
\mathrm{n}=284\end{array}$ & $\begin{array}{l}\text { To assess fall risk in hospitalized } \\
\text { elderly people. }\end{array}$ & $\begin{array}{l}\text { The use of specific tools in fall prevention } \\
\text { allows the improvement of the quality of } \\
\text { care based on scientific evidence. }\end{array}$ & $\begin{array}{l}\text { Clinical assessment and } \\
\text { fall prevention. }\end{array}$ \\
\hline $\begin{array}{l}\text { LeLaurin and } \\
\text { Shorr } \\
2019^{(21)} \\
\text { United States of } \\
\text { America }\end{array}$ & Literature review & $\begin{array}{l}\text { To analyze the drawings of common } \\
\text { studies and the evidence of various } \\
\text { hospital interventions of fall } \\
\text { prevention. }\end{array}$ & $\begin{array}{l}\text { There is an urgent need for well-designed } \\
\text { research on the theme of hospital fall } \\
\text { prevention. }\end{array}$ & $\begin{array}{l}\text { Clinical assessment and } \\
\text { fall prevention. }\end{array}$ \\
\hline $\begin{array}{l}\text { Chan et al. } \\
2019^{(22)} \\
\text { Singapore }\end{array}$ & $\begin{array}{l}\text { Qualitative study } \\
\mathrm{n}=30\end{array}$ & $\begin{array}{l}\text { To explore the perceptions of nurses } \\
\text { about their participation in the } \\
\text { physical activity of elderly patients. }\end{array}$ & $\begin{array}{l}\text { Culturally appropriate strategies at the } \\
\text { organizational and individual levels are } \\
\text { necessary to reinvigorate nurses and } \\
\text { optimize participation in physical activity. }\end{array}$ & Fall risk factors. \\
\hline $\begin{array}{l}\text { Kiyoshi-Teo et al. } \\
2019^{(23)} \\
\text { United States of } \\
\text { America }\end{array}$ & Documentary research & $\begin{array}{l}\text { To identify associations between } \\
\text { risk factors, perceptions and daily } \\
\text { activities of patients. }\end{array}$ & $\begin{array}{l}\text { Address measures, include validated } \\
\text { tools, and modified fall behavioral scale } \\
\text { in a patient-centered way, such as daily } \\
\text { perceptions and activities. These actions } \\
\text { prevent patients from falls. }\end{array}$ & $\begin{array}{l}\text { Fall prevention } \\
\text { strategies. }\end{array}$ \\
\hline $\begin{array}{l}\text { Grealish et al. } \\
2019^{(24)} \\
\text { Australia }\end{array}$ & $\begin{array}{l}\text { Qualitative study } \\
\mathrm{n}=17\end{array}$ & $\begin{array}{l}\text { To explore reflections of nurses and } \\
\text { nursing assistants about the care } \\
\text { of elderly patients with cognitive } \\
\text { impairment who suffered a fall. }\end{array}$ & $\begin{array}{l}\text { Participants knew the policy and } \\
\text { techniques available to prevent falls, but } \\
\text { their implementation was challenging } \\
\text { due to the complexity of care required by } \\
\text { elderly people with cognitive impairment. }\end{array}$ & $\begin{array}{l}\text { Clinical assessment and } \\
\text { fall prevention. }\end{array}$ \\
\hline $\begin{array}{l}\text { Smith et al. } \\
2018^{(25)} \\
\text { Australia }\end{array}$ & $\begin{array}{l}\text { Quantitative study } \\
\mathrm{n}=653\end{array}$ & $\begin{array}{l}\text { To determine whether patients' } \\
\text { time in care resulted in lower } \\
\text { adverse events and incidents when } \\
\text { compared to patients admitted } \\
\text { to mental health wards of elderly } \\
\text { people. }\end{array}$ & $\begin{array}{l}\text { The characteristics of the reported } \\
\text { adverse events appeared similar and } \\
\text { there seems to be no substantial } \\
\text { difference between the wards that } \\
\text { entered the study. }\end{array}$ & $\begin{array}{l}\text { Fall prevention } \\
\text { strategies. }\end{array}$ \\
\hline
\end{tabular}


Chart 1

\begin{tabular}{|c|c|c|c|c|}
\hline $\begin{array}{l}\text { Authors year/ } \\
\text { country }\end{array}$ & Design & Objective & Main results & Thematic content \\
\hline $\begin{array}{l}\text { Shyu et al. } \\
2018^{(26)} \\
\text { China }\end{array}$ & $\begin{array}{l}\text { Quantitative study } \\
\mathrm{n}=600\end{array}$ & $\begin{array}{l}\text { To develop the Self-Awareness scale } \\
\text { of Falls in the Elderly (SAFE) and test } \\
\text { its reliability. }\end{array}$ & $\begin{array}{l}\text { Combining the SAFE scale with other fall } \\
\text { assessment tools can help the care team } \\
\text { effectively assess the self-awareness of } \\
\text { fall risk. }\end{array}$ & $\begin{array}{l}\text { Fall prevention } \\
\text { strategies. }\end{array}$ \\
\hline $\begin{array}{l}\text { Oliveira et al. } \\
2018^{(27)} \\
\text { Brazil }\end{array}$ & $\begin{array}{l}\text { Quantitative study } \\
n=424\end{array}$ & $\begin{array}{l}\text { To identify extrinsic factors favorable } \\
\text { to the occurrence of falls of } \\
\text { hospitalized elderly patients. }\end{array}$ & $\begin{array}{l}\text { Knowing the profile of elderly people } \\
\text { and extrinsic factors will enable health } \\
\text { professionals to identify the risks and } \\
\text { provide safe care. }\end{array}$ & Fall risk factors. \\
\hline $\begin{array}{l}\text { Oliveira et al. } \\
2017^{(28)} \\
\text { Brazil }\end{array}$ & $\begin{array}{l}\text { Quantitative study } \\
\mathrm{n}=96\end{array}$ & $\begin{array}{l}\text { To assess the occurrence of fall in } \\
\text { hospitalized patients who presented } \\
\text { high risk for the event. }\end{array}$ & $\begin{array}{l}\text { Falls are directly linked to patient safety } \\
\text { indicators, and a multidisciplinary and } \\
\text { interdisciplinary approach is necessary. }\end{array}$ & $\begin{array}{l}\text { Clinical assessment and } \\
\text { fall prevention. }\end{array}$ \\
\hline $\begin{array}{l}\text { Victor et al. } \\
2017^{(29)} \\
\text { Brazil }\end{array}$ & $\begin{array}{l}\text { Quantitative study } \\
\mathrm{n}=70\end{array}$ & $\begin{array}{l}\text { To describe the adverse fall event in } \\
\text { patients hospitalized in surgical units. }\end{array}$ & $\begin{array}{l}\text { Nurses should be aware of risk factors to } \\
\text { intervene and prevent events. }\end{array}$ & Fall risk factors. \\
\hline $\begin{array}{l}\text { Durán et al. } \\
2017^{(30)} \\
\text { Spain }\end{array}$ & $\begin{array}{l}\text { Descriptive, } \\
\text { observational and } \\
\text { retrospective study } \\
n=99\end{array}$ & $\begin{array}{l}\text { To determine the incidence and } \\
\text { characteristics of falls in elderly } \\
\text { hospitalized. }\end{array}$ & $\begin{array}{l}\text { Nursing interventions in the HSPV were } \\
\text { oriented towards strengthening fall } \\
\text { prevention in patients with cardiovascular } \\
\text { pathology and in polymedicated patients. }\end{array}$ & $\begin{array}{l}\text { Clinical assessment and } \\
\text { fall prevention. }\end{array}$ \\
\hline $\begin{array}{l}\text { Kobayashi } \\
\text { et al. } \\
2017^{(31)} \\
\text { Japan }\end{array}$ & $\begin{array}{l}\text { Quantitative study } \\
n=212,617\end{array}$ & $\begin{array}{l}\text { To examine fall prevention due to fall } \\
\text { work group intervention established } \\
\text { in hospital. }\end{array}$ & $\begin{array}{l}\text { The decrease in patients at risk of grade } \\
3 \text { did not decrease, but increased; on the } \\
\text { other hand, the decrease in grade } 1 \text { and } \\
2 \text { patients decreased, suggesting that } \\
\text { better information sharing is needed for } \\
\text { patients with high fall risk. }\end{array}$ & $\begin{array}{l}\text { Clinical assessment and } \\
\text { fall prevention. }\end{array}$ \\
\hline $\begin{array}{l}\text { Esparza- } \\
\text { Bohórquez et al. } \\
2017^{(32)} \\
\text { Colombia }\end{array}$ & $\begin{array}{l}\text { Quantitative study } \\
\mathrm{N}=2,387\end{array}$ & $\begin{array}{l}\text { To reduce falls in the old people in } \\
\text { hospitalization services. }\end{array}$ & $\begin{array}{l}\text { The implementation of evidence-based } \\
\text { nursing guides generates a positive effect } \\
\text { on the quality of care, obtaining results } \\
\text { that affect the health and well-being of } \\
\text { patients. }\end{array}$ & $\begin{array}{l}\text { Clinical assessment and } \\
\text { fall prevention. }\end{array}$ \\
\hline $\begin{array}{l}\text { Hill et al. } \\
2016^{(33)} \\
\text { Australia }\end{array}$ & $\begin{array}{l}\text { Qualitative study } \\
\mathrm{n}=30\end{array}$ & $\begin{array}{l}\text { To understand how the team } \\
\text { responded to individualized } \\
\text { education for fall prevention of } \\
\text { patients. }\end{array}$ & $\begin{array}{l}\text { Providing individualized education to } \\
\text { elderly patients with good levels of } \\
\text { cognition can empower the team. }\end{array}$ & $\begin{array}{l}\text { Clinical assessment and } \\
\text { fall prevention. }\end{array}$ \\
\hline $\begin{array}{l}\text { Mazur et al. } \\
2016^{(34)} \\
\text { Poland }\end{array}$ & $\begin{array}{l}\text { Quantitative study } \\
\mathrm{n}=788\end{array}$ & $\begin{array}{l}\text { To assess the factors associated } \\
\text { with falls in geriatric patients after } \\
\text { the implementation of the fall } \\
\text { prevention program. }\end{array}$ & $\begin{array}{l}\text { Delirium, history of falls and advanced } \\
\text { age seem to be the main risk factors for } \\
\text { geriatric falls. }\end{array}$ & $\begin{array}{l}\text { Clinical assessment and } \\
\text { fall prevention. }\end{array}$ \\
\hline $\begin{array}{l}\text { Meuleners et al. } \\
2016^{(35)} \\
\text { Australia }\end{array}$ & $\begin{array}{l}\text { Quantitative study } \\
\mathrm{n}=32,519\end{array}$ & $\begin{array}{l}\text { To identify risk factors for } \\
\text { recurrent harmful falls that require } \\
\text { hospitalization in adults over } 60 \\
\text { years of age with dementia. }\end{array}$ & $\begin{array}{l}\text { Screening those with dementia for the } \\
\text { history of harmful falls could help identify } \\
\text { those with higher fall risk. }\end{array}$ & Fall risk factors. \\
\hline $\begin{array}{l}\text { Oliveira et al. } \\
2016^{(36)} \\
\text { Brazil }\end{array}$ & Qualitative study & $\begin{array}{l}\text { To develop an instrument to assess } \\
\text { the vulnerability of hospitalized } \\
\text { elderly people in relation to falls. }\end{array}$ & $\begin{array}{l}\text { The instrument for assessing falls in } \\
\text { hospitalized elderly people is additional in } \\
\text { the work process. }\end{array}$ & $\begin{array}{l}\text { Clinical assessment and } \\
\text { fall prevention. }\end{array}$ \\
\hline $\begin{array}{l}\text { Latt et al. } \\
2016^{(37)} \\
\text { Australia }\end{array}$ & $\begin{array}{l}\text { Quantitative study } \\
\mathrm{n}=217\end{array}$ & $\begin{array}{l}\text { To examine the validity of Ontario } \\
\text { Modified STRATIFY (OM). }\end{array}$ & $\begin{array}{l}\text { Screening tools have limited accuracy in } \\
\text { identifying patients with high fall risk. }\end{array}$ & $\begin{array}{l}\text { Clinical assessment and } \\
\text { fall prevention. }\end{array}$ \\
\hline $\begin{array}{l}\text { Said et al. } \\
2016^{(38)} \\
\text { Australia }\end{array}$ & $\begin{array}{l}\text { Quantitative study } \\
\mathrm{n}=121\end{array}$ & $\begin{array}{l}\text { To determine whether patients } \\
\text { hospitalized in rehabilitation with } \\
\text { high fall risk receive adequate } \\
\text { assessment, management and care. }\end{array}$ & $\begin{array}{l}\text { There was little evidence that people } \\
\text { with high fall risk received systematic } \\
\text { assessment of fall risk during } \\
\text { rehabilitation. }\end{array}$ & $\begin{array}{l}\text { Clinical assessment and } \\
\text { fall prevention. }\end{array}$ \\
\hline $\begin{array}{l}\text { Fernandes et al. } \\
2015^{(39)} \\
\text { Brazil }\end{array}$ & $\begin{array}{l}\text { Quantitative study } \\
\mathrm{n}=59\end{array}$ & $\begin{array}{l}\text { To characterize the fall risk in elderly } \\
\text { men hospitalized in a hospital } \\
\text { environment. }\end{array}$ & $\begin{array}{l}\text { Risk factors for fall related to clinical, } \\
\text { physiological, environmental, cognitive } \\
\text { and drug conditions were identified. }\end{array}$ & Fall risk factors. \\
\hline
\end{tabular}




\begin{tabular}{|l|l|l|l|l|}
\hline $\begin{array}{l}\text { Authors year/ } \\
\text { country }\end{array}$ & Design & Objective & Main results & Thematic content \\
\hline $\begin{array}{l}\text { Vass et al. } \\
2015^{(40)} \\
\text { England }\end{array}$ & $\begin{array}{l}\text { Qualitative study } \\
\mathrm{n}=675\end{array}$ & $\begin{array}{l}\text { Assessment of the service to } \\
\text { examine and describe the style and } \\
\text { quality of footwear used by elderly } \\
\text { patients in the hospital. }\end{array}$ & $\begin{array}{l}\text { It was found that 46\% of hospitalized } \\
\text { elderly people use slippers and } 60 \% \text { of the } \\
\text { shoes have moderate to excessive wear, } \\
\text { not promoting stability or ideal gait for } \\
\text { elderly people. }\end{array}$ & Fall risk factors. \\
\hline $\begin{array}{l}\text { Abreu et al. } \\
\begin{array}{l}\text { Brazil } \\
\text { B(4) }\end{array}\end{array}$ & $\begin{array}{l}\text { Quantitative study } \\
\mathrm{n}=221\end{array}$ & $\begin{array}{l}\text { To estimate the incidence and } \\
\text { predictors associated with falls in } \\
\text { elderly patients. }\end{array}$ & $\begin{array}{l}\text { Predictors such as educational level, } \\
\text { polypharmacy, visual impairment, } \\
\text { gait and balance impairment, urinary } \\
\text { incontinence and use of laxatives and } \\
\text { antipsychotics predispose to fall. }\end{array}$ & Fall risk factors. \\
\hline $\begin{array}{l}\text { Hill et al. } \\
2015^{(42)} \\
\text { Australia }\end{array}$ & $\begin{array}{l}\text { Qualitative study } \\
\mathrm{n}=10\end{array}$ & $\begin{array}{l}\text { To explore educators' perspectives of } \\
\text { providing education. }\end{array}$ & $\begin{array}{l}\text { Individualized fall prevention education } \\
\text { effectively provides patients who receive } \\
\text { the ability and motivation to develop } \\
\text { and undertake behavioral strategies that } \\
\text { reduce their falls. }\end{array}$ & Fall risk factors. \\
\hline
\end{tabular}

Scientific productions on nursing care related to fall risk prevention of hospitalized elderly people were analyzed. It is noteworthy that 2019 was the year with the highest number of publications (15). As for the country where the studies were carried out, they are distributed as follows: Norway (1), United States of America (5), Japan (2), Australia (8), Brazil (9), Portugal (1), China (2), Singapore (1), Spain (1), Colombia (1), Poland (1), and England (1).

The relevant number of productions made by nurses was evidenced, considering the direct care provided by nursing to elderly hospitalized patients, which led to the formation of three categories: clinical assessment made by nurses for fall prevention of hospitalized elderly people ${ }^{(11,20-21,24,2,3,2,38)}$; identification of fall risk factors in elderly people ${ }^{(10,12-14,17,19,22,27,29,35,39-42)}$; fall risk prevention strategies for elderly people $e^{(11,15-18,23,25-26,29-31,33-34,36-37)}$.

\section{DISCUSSION}

From analysis of the articles, three thematic categories were established that constituted the synthesis of the analyzed studies: clinical assessment made by nurses for fall prevention of hospitalized elderly; identification of risk factors for falls among elderly people; fall risk prevention strategies for elderly people, as shown below.

\section{Clinical assessment made by nurses for fall prevention of hospitalized elderly people}

Nurses, in the performance of their activities, assistance, or research, envision conquering scientific and technological advances to apply them in the field of activity and interest. This search is strengthened as the professional manages to establish his identity and improve his performance, based on clinical effectiveness through evidence-based practice (EBP) ${ }^{(43)}$. EBP contributes to improving the clinical assessment of nurses in decision-making and are essential for patient safety, contributing to meeting their biopsychosocial needs. Evidence-based fall prevention initiatives need to be consistent and clear in their approach, requiring professional leadership and innovation effective for their applicability and, mainly, directed to the particularities and individualities of each patient, ensuring, in fact, the care for fall prevention in hospitalized elderly ${ }^{(10,32,38,43)}$. These events have consequences for patients' health, in addition to the increase in costs of care expenses during hospitalization, depending on the complexity caused by this event to elderly people and the health institution ${ }^{(44)}$.

In this sense, there is a need for the restructuring of nursing services on an ongoing basis in relation to strengthening the nursing team, investments in training, with improvement of clinical judgment, so that possible limitations in their professional performance are reduced to the maximum. Fall prevention programs based on scientific evidence are transformational mechanisms in addressing the concrete elderly people's needs during hospitalization ${ }^{(10,28)}$.

Nurses feel challenged to assume a transformative and innovative professional posture when seeking evidence-based clinical practice in caring for elderly people. Critical thinking and clinical reasoning, adopted in decision making, accurately and safely, with updated knowledge and grounded in studies with better scientific evidence, direct their care practice individually to the specificity of care for hospitalized elderly ${ }^{(24,32,45)}$.

In addition to the clinical assessment based on EBP, nurses can evaluate the patient through the nursing history or clinical investigation, which consists of the first stage of anamnesis and physical examination of nursing, as proposed by Wanda de Aguiar Horta and developed from Maslow's Theory of Human Motivation ${ }^{(46)}$. Thus, from the moment the nurse has the data collected in the nursing history and the physical examination of the patient, he is able to identify the nursing problems and the affected Basic Human Needs, making it possible, then, to establish clinical judgment on the patient responses ${ }^{(47)}$.

However, there is an urgent need for well-structured research and well-founded projects on fall prevention in the hospital environment. Moreover, it is important that the results of research with scientific evidence are not limited, but demonstrate the effectiveness of interventions to meet each patient's needs ${ }^{(20-21)}$.

It is pointed out that the clinical assessment made by nurses precisely, based on the best scientific evidence found and, above 
all, with EBP, is considered a challenge to be faced by nurses, as it requires dedication, commitment and acquisition of knowledge that favors skills necessary for clinical practice.

\section{Identification of risk factors for falls among elderly people}

In the studies included in this category ${ }^{(10,12-14,17,19,22,27,29,35,39-42)}$, the factors identified as fall risk of the hospitalized elderly were related to clinical, cognitive, medication and extrinsic factors. Such studies indicate that failure to identify these factors can produce limited strategies, making their prevention difficult.

Regarding medications, previous national surveys indicated that the use of antihypertensive drugs and sedatives was associated with an increased risk of falls in hospitalized elderly patients ${ }^{(37,39)}$. Elderly people may become more susceptible to falls due to physiological changes in cardiovascular reflexes; associated with this, the use of medications is one of the few modifiable risk factors that can be changed during hospitalization. Therefore, it is up to the nurse to identify elderly people's specific drug therapy and the probability of presenting risks of falling. Identifying elderly people's frailties, for instance, using instruments to assess the fear of falling, which an elderly person may present, should also be part of the nurse's routine, as this is a variable considered as a potential fall risk factor in the hospital ${ }^{(48)}$.

Another point to note is that attention and care with the feet and toenails can improve the condition of the muscular strength of the lower limbs and the distribution of pressure in the feet, providing balance during walking and, consequently, decreasing the fall risk and contributing to their mobility and social interaction ${ }^{(12-14)}$.

As for extrinsic factors, the nursing team, in its assessment, must identify those that can favor the occurrence of falls among elderly people during hospitalization. Among these factors, the arrangement of furniture in the rooms and the habits and customs of elderly people ${ }^{(42)}$, related to the use of footwear, are the ones that stand out, exposing elderly people to falling ${ }^{(27,29)}$. It is known that the lack of distribution or the excess of furniture in the rooms can hinder mobility and, consequently, make the environment unsafe, as well as the misuse of footwear or the use of inappropriate footwear provides instability when moving, leaving elderly people in a condition of susceptibility to falling.

The literature in question analyzed points out that it is important for nurses to identify the fall risk factors involved in elderly people' hospitalization process and implement preventive measures early, in addition to using individualized education for elderly people as a tool for fall prevention in the hospital environment. Such initiatives contribute so that this target audience understands the risks and starts to feel motivated to execute behavioral strategies that reduce the possible occurrences of the event, as evidenced in previous studies ${ }^{(10,17,19,35)}$.

\section{Fall risk prevention strategies among elderly people}

For fall prevention among elderly people who present high risk, it is suggested that the greatest possible sharing of information be established between the work groups, that is, that there is visibility in relation to the risk and exposure to which elderly people are vulnerable ${ }^{(30,33)}$.
Scientific data show that studies that used the implementation of guides to good nursing practices based on scientific evidence to reduce falls among elderly people during hospitalization generated positive effects on the quality of care, fall prevention and possible injuries resulting from this event, resulting in improving patients' health and well-being ${ }^{(23,34)}$.

The presence of nursing in the care directed to elderly people and in fall prevention is extremely important, mainly due to the technical responsibility of these professionals in providing care to patients. For individualized care to occur ${ }^{(11,30)}$, intentional rounds in the room or in the wards during the working day stand out. These practices are considered transformative and contribute to elder care in these conditions.

Based on the results of the studies presented, it is understood that the instruments used by the authors who assessed fall risk among elderly people can be applied as strategies to prevent the occurrence of this event. The application of these instruments is important to identify, in the inpatient units, the number of hospitalized patients aged over 60 years and assessed with high fall risk ${ }^{(15,25-26)}$.

Among the assessment instruments for fall risk, the Morse scale and the fall risk assessment of Wilson Sims stand out; both can be used in the hospital to identify the fall risk factors in elderly people, comparing their results. A 2015 survey $^{(16)}$ applied these tools in research with hospitalized elderly people suffering from dementia, and concluded that elderly women with dementia were at higher risk for falls (75\%) and that $50 \%$ of occurrences took place on the way to the bathroom, especially at night, in which there is a decrease in the number of nursing professionals. A study on the occurrence of falls in the hospital environment in North American countries found that between $38 \%$ and $47 \%$ of falls occur in hospital bathrooms in elderly people's performance in hygiene and physiological activities ${ }^{(49)}$.

Another instrument used to assess fall risk among elderly people is the Assessment of Siderail Use, an instrument developed in the United States to assess the use or not of siderails, consisting of four stages: resident preference; assessment of the risk of damage such as falling, trapping, bruising, skin lesions; bed fall risk; intervention alternatives, presenting recommendations for prevention and reducing the use of restraint/siderails. This instrument was translated and adapted to Brazilian Portuguese ${ }^{(16)}$. Therefore, as an alternative intervention to reduce elderly people's falls from the bed, the bed siderail can be considered. However, the authors analyze the effects of systematic assessment for the decision to raise or not the siderail, highlighting that this decision must be based on the individual needs of each patient and adapted to meet them, minimizing the unnecessary use of siderails as mechanical restraint ${ }^{(16,31)}$.

Therefore, other clinical assessments of the hospitalized elderly should not be disregarded, as these contribute to facilitate assessing the individual profile and the possible vulnerabilities of elderly people during hospitalization; above all, they provide the opportunity to program care strategies and strategies for fall prevention ${ }^{(29,36-37)}$.

The results of the studies included in the present review support the care practice and contribute to its realization. They also add to the production of knowledge on the topic of safety and care for hospitalized elderly people. The results and conclusions 
of the works were explanatory, complementing the objectives proposed by the authors in each article.

\section{Study limitations}

The limitations of this study are present in the delimitation of the researched time, of only five years, and in the search for studies on nursing care without adhering to studies on the vision of hospitalized elderly people.

\section{Contributions to nursing}

The study directly contributes to gerontological care practice, with studies that address the occurrence of falls among elderly people during hospitalization, presenting a scientific panorama with updated evidence in nursing and care for the fall risk prevention of hospitalized elderly people through articles published in national and international journals. Moreover, specific and comprehensive knowledge in this area contributes to the instrumentalization of nursing for patient safety.

\section{FINAL CONSIDERATIONS}

Among the 33 articles found in this ILR, 22 had the exclusive authorship of nurses, who considered the importance of carrying out studies on fall prevention of elderly people. The synthesis of the studies showed the importance of the clinical assessment made by the nurse for the fall prevention of hospitalized elderly people as a fundamental element to identify hospitalized elderly people with different levels of vulnerability and risk of falling. Moreover, it showed, from clinical assessment, sharing information between the working groups to give visibility to the risk that elderly people may be exposed and planning strategies that will protect the hospitalized elderly person from an adverse event, among them the information for elderly people to encourage self-care.

The studies highlighted that the risk factors for falls are related to clinical, physiological, cognitive and medication conditions, in addition to environmental conditions, which can put them in a situation of vulnerability to falls.

Studies still highlight among the individual factors: the use of inappropriate shoes during hospitalization; the condition of the feet and nails, responsible for elderly people' balance; inpatient unit of elderly people, leading to a higher risk of an accident.

The review contributes to better gerontological nursing practices, offering a basis for future studies in which professionals can deepen the categories identified here, with a view to developing specific skills in the care of hospitalized elderly people, related risk factors paying attention to hospitalized elderly people surveillance, especially those assessed with fall risk, and mobilizing their potential for self-care.

\section{REFERENCES}

1. Ministério da Saúde (BR). Anexo 01: Protocolo de Prevenção de Quedas. Protocolo Integrante do Programa Nacional de Segurança do Paciente [Internet]. 2013 [cited 2020 Oct 08]. Available from: https://www20.anvisa.gov.br/segurancadopaciente/index.php/publicacoes/ item/prevencao-de-quedas

2. Meneguin S, Banja PFT, Ferreira MLS. Cuidado ao paciente idoso hospitalizado: implicações para a equipe de enfermagem. Rev Enferm UERJ. 2017;25(N.Esp):1-6. https://doi.org/10.12957/reuerj.2017.16107

3. Sarges NA, Santos MIPO, Chaves EC. Evaluation of the safety of hospitalized older adults as for the risk of falls. Rev Bras Enferm. 2017;70(4):860-7. https://doi.org/10.1590/0034-7167-2017-0098

4. Cavalcante AKCB, Rocha RC, Avelino FVSD, Rocha SS. Cuidado seguro ao paciente: contribuições da enfermagem. Rev Cubana Enferm [Internet]. 2015 [cited $2020 \mathrm{Jul}$ 27];31(4). Available from: http://www.revenfermeria.sld.cu/index.php/enf/article/view/907

5. Kahl C, Meirelles BHS, Lanzoni GMM, Koerich C, Cunha KS. Actions and interactions in clinical nursing practice in Primary Health Care. Rev Esc Enferm USP. 2018;52:e03327. https://doi.org/10.1590/S1980-220X2017025503327

6. Santos TD, Espírito Santo FH, Cunha KCS, Chibante CLP. Segurança do paciente idoso hospitalizado: uma revisão integrativa. Cogitare Enferm. 2016;21(3). https://doi.org/10.5380/ce.v21i3.44223

7. Canuto CPAS, Oliveira LPBA, Medeiros MRS, Barros WCTS. Safety of hospitalized older adult patients: an analysis of the risk of falls. Rev Esc Enferm USP. 2020;54:e03613. https://doi.org/10.1590/S1980-220X2018054003613

8. Soares CB, Hoga LAK, Peduzzi M, Sangaleti C, Yonekura T, Silva DRAD. Revisão integrativa: conceitos e métodos utilizados na enfermagem. Rev Esc Enferm Enfermagem. 2014;48(2):335-45. https://doi.org/10.1590/S0080-6234201400002000020

9. Ganong LH. Integrative reviews of nursing research. Res Nurs Health. 1987;10(1):1-11. https://doi.org/10.1002/nur.4770100103

10. Royset B, Talseth-Palmer BA, Lydersen S, Farup PG. Effects of a fall prevention program in elderly: a pragmatic observational study in two orthopedic departments. Clin Interv Aging. 2019;14:145-54. https://doi.org/10.2147/CIA.S191832

11. Fridman V. Redesigning a fall prevention program in acute care: building on evidence. Clin Geriatr Med. 2019;35(2):265-71. https://doi. org/10.1016/j.cger.2019.01.006

12. Yamashita T, Yamashita K, Rinoie C, Takase Y, Sato M, Yamada K, et al. Improvements in lower-limb muscle strength and foot pressure distribution with foot care in frail elderly adults: a randomized controlled trial from Japan. BMC Geriatr. 2019;19(83):2-9. https://doi.org/10.1186/s12877-019-1097-z

13. Bolton L. Preventing fall injury. Wounds[Internet]. 2019 [cited 2020 Jul 27];31(10):269-71. Available from: https://pubmed.ncbi.nlm.nih. gov/31730506/ 
14. Toye C, Slatyer S, Kitchen S, Ingram K, Bronson M, Edwards D, et al. Bed moves, ward environment, staff perspectives and falls for older people with high falls risk in an acute hospital: a mixed methods study. Clin Interv Aging. 2019;14:2223-37. https://doi.org/10.2147/CIA.S211424

15. Souza AB, Maestri RN, Röhsig V, Lorenzini E, Alves BM, Oliveira D, et al. In-hospital falls in a large hospital in the south of Brazil: a 6-year retrospective study. Appl Nurs Res. 2019;48:81-7. https://doi.org/10.1016/j.apnr.2019.05.017

16. Ferreira TCB, Santana RF, Carmo TGS, Souza MV, Souza, LSM. Instrumentos para avaliação do uso de grades laterais do leito: segurança ou contenção? Nurs [Internet]. 2019 [cited 2020 Jul 29];22(254):3052-9. Available from: http://www.revistanursing.com.br/revistas/254/pg35.pdf

17. Cunha LFC, Baixinho CL, Henriques MA. Preventing falls in hospitalized elderly: design and validation of a team intervention. Rev Esc Enferm USP. 2019;53:e3479. https://doi.org/10.1590/S1980-220X2018031803479

18. Wong MMC, Pang PF. Factors associated with falls in psychogeriatric inpatients and comparison of two fall risk assessment tools. East Asian Arch Psychiatry [Internet]. 2019 [cited 2020 Jul 29];29(1):10-4. Available from: https://easap.asia/abstracts/v29n1/1901_V29N1_p10a.html

19. Dolan H, Taylor-Piliae R. Selecting a theoretical framework to guide a research study of older adults' perceptions and experiences of falling in the hospital. Appl Nurs Res. 2019;47:38-40. https://doi.org/10.1016/j.apnr.2019.04.004

20. Falcão RMM, Costa KNFM, Fernandes MGM, Pontes MLF, Vasconcelos JMB, Oliveira JS. Risk of falls in hospitalized elderly people. Rev Gaúcha Enferm. 2019;40(N.Esp.):1-8. 22. https://doi.org/10.1590/1983-1447.2019.20180266

21. LeLaurin JH, Shorr R. Preventing falls in hospitalized patients: state of the science. Clin Geriatr Med. 2019; 35(2):273-283. https://doi. org/10.1016/j.cger.2019.01.007

22. Chan EY, Hong MLI, Tan MYHG, Chua WL. Older patient's participation in physical activity during hospitalization: a qualitative study of ward nurses' perceptions in an Asian context. Geriatr Nurs. 2019;40(1):91-8. https://doi.org/10.1016/j.gerinurse.2018.07.002

23. Kiyoshi-Teo H, Northrup-Snyder K, Cohen DJ, Dieckmann N, Stoyles S, Winters-Stone K, et al. Older hospital inpatients' fall risk factors, perceptions, and daily activities to prevent falling. Geriatr Nurs. 2019;40(3):290-5. https://doi.org/10.1016/j.gerinurse.2018.11.005

24. Grealish L, Chaboyer W, Darch J, Real B, Phelan M, Soltau D, et al. Caring the person with cognitive impairment in hospital: qualitative analysis of nursing personnel reflections on fall events. Clin Nurs. 2019;28(7-8):1346-53. https://doi.org/10.1111/jocn.14724

25. Smith T, Clark A, Dodd E, Khoo ME, Heneker S, Cross J, et al. Feasibility study suggests no impact from protected engagement time on adverse events in mental health wards for older adults. Int J Ment Health Nurs. 2018;27(2):756-764. https://doi.org/10.1111/inm.12362

26. Shyu ML, Huang HC, Wu MJ, Chang HJ. Development and validation of the self-awareness of falls in elderly scale among elderly inpatients. Clin Nurs Res. 2018;27(1):105-20. https://doi.org/10.1177/1054773817714663

27. Chaves BJP, Oliveira JS, Rodrigues MMP, Falcão RMM, Souza SVO, Carvalho EAS, et al. Fatores extrínsecos para risco de quedas de idosos hospitalizados. Rev Enferm UFPE. 2018;12(7):1835-40. https://doi.org/10.5205/1981-8963-v12i7a231271p1835-1840-2018

28. Oliveira DU, Ercole FF, Melo LS, Matos SS, Campos CC, Fonseca EAM. Avaliação de quedas em idosos hospitalizados. Rev Enferm UFPE. 2017;11(suple):4589-97. https://doi.org/10.5205/reuol.11138-99362-1-SM.1111sup201707

29. Victor MAG, Luzia MF, Severo IM, Almeida MA, Goes MGO, Lucena AF. Quedas em pacientes cirúrgicos: subsídios para o cuidado de enfermagem seguro. Rev Enferm UFPE. 2017;11(Supl.10):4027-35. https://doi.org/10.5205/reuol.10712-95194-3-SM.1110sup201704

30. Durán ER, Camarero GFR, Martínez-Esparza EH. Incidencia y características de las caídas en un hospital de cuidados intermedios de Barcelona. Gerokomos [Internet]. 2017[cited 2020 Jul 29];28(2):78-82. Available from: http://scielo.isciii.es/pdf/geroko/v28n2/1134-928Xgeroko-28-02-78.pdf

31. Kobayashi K, Ando K, Inagaki Y, Suzuki Y, Nagao Y, Ishiguro N, et al. Measures and effects on prevention of fall: the role of a fall working group at a university hospital. Nagoya J Med. Sci. 2017;79:497-504. https://doi.org/10.18999/nagjms.79.4.497

32. Esparza-Bohórquez M, Granados-Oliveros LM, Serrano-Sanmiguel E, Peñaloza-Jaimes S. Prevención de caídas y lesiones derivadas en adultos mayores hospitalizados: experiencia de cuidado de enfermería de la aplicación de una guía de buenas prácticas en la Fundación Oftalmológica de Santander. MedUnab. 2017;20(2):174-81. https://doi.org/10.29375/01237047.3246

33. Hill AM, Nicholas W, Francis-Coad J, Haines T, Etherton-Beer C, Flicker L, et al. 'It Promoted a Positive Culture Around Falls Prevention': staff response to a patient education programme-a qualitative evaluation. BMJ Open. 2016;6(12):1-7. https://doi.org/10.1136/ bmjopen-2016-013414

34. Mazur K, Wilczyński K, Szewieczek J. Geriatric falls in the context of a hospital fall prevention program: delirium, low body mass index, and other risk factors. Clin Interv Aging. 2016;14(11):1253-61. https://doi.org/10.2147/CIA.S115755

35. Meuleners LB, Fraser ML, Bulsara MK, Chow K, Jonathon QN. Risk factors for recurrent injurious falls that require hospitalization for older adults with. dementia: a population based study. BMC Neurol. 2016;16(1):1-8. https://doi.org/10.1186/s12883-016-0711-3

36. Oliveira DM, Hammerschmidt KSA, Schoeller SD, Girondi JBR, Bertoncello KCG, Paula Jr NF. Instrumento de avaliação de quedas em idosos hospitalizados (IAQI HOSPITALAR): enfermeiro analisando vulnerabilidade e mobilidade. Rev Enferm UFPE. 2016;10(11):4065-74. https://doi. org/10.5205/1981-8963-v10i11a11491p4065-4074-2016

37. Latt MD, Loh KF, Ge L, Hepworth A. The validity of three fall risk screening tools in an acute geriatric inpatient population. Australas J Ageing. 2016;35(3):167-73. https://doi.org/10.1111/ajag.12256

38. Said CM, Batchelor F, Shaw K, Blennerhassett J. Preparing patients at high risk of falls for discharge home after rehabilitation: do we meet the guidelines? Geriatr Gerontol Int. 2016;16(5):570-6. https://doi.org/10.1111/ggi.12511 
39. Fernandes APNL, Araújo AKC, Botarelli FR, Araújo JMN, Ferreira Jr MA, Vitor AL. Risco de quedas e a saúde do homem: desafios do cuidado na internação hospitalar. Rev Enferm UFPE[Internet]. 2015[cited 2020 Jul 23];9(10):9541-9. Available from: https://periodicos.ufpe.br/ revistas/revistaenfermagem/article/view/10899

40. Vass C, Edwards C, Smith A, Sahota O, Drummond A. What do patients wear on their feet? A service evaluation of footwear in elderly patients. Int J Ther Rehabil. 2015;22(5):21-28. https://doi.org/10.12968/ijtr.2015.22.5.225.

41. Abreu HCA, Reiners AAO, Azevedo RCS, Silva AMC, Abreu DROM, Oliveira AD. Incidência e fatores preditores de quedas de idosos hospitalizados. Rev Saúde Pública. 2015;49(37):1-9. https://doi.org/10.1590/S0034-8910.2015049005549

42. Hill AM, McPhail SM, Francis-Coad J, Waldron N, Etherton-Beer C, Flicker L, et al. Educators perspectives about how older hospital patients can engage in a falls prevention education programme: a qualitative process evaluation. BMJ Open. 2015;5:1-8. https://doi.org/10.1136/ bmjopen-2015-009780

43. Camargo FC, Iwamoto HH, Monteiro DAT, Lorena LT, Pereira GA. Avaliação de intervenção para difusão da enfermagem baseada em evidências em hospital de ensino. Rev Gaúcha Enferm. 2016;37(n. esp.):1-9. https://doi.org/10.1590/1983-1447.2016.esp.68962

44. Rheaume J, Fruh S. Retrospective case reviews of adult inpatient falls in the acute care setting. Medsurg Nurs [Internet]. 2015 [cited 2020 Jul 28];24(5):318-24. Available from: https://pubmed.ncbi.nlm.nih.gov/26665867/

45. Borges CL, Freitas MC, Guedes MVC, Silva MJ, Leite SFP. Nursing clinical practice in the frail elderly care: reflection study. J Nurs UFPE. 2016;10(2):914-8. https://doi.org/10.5205/1981-8963-v10i2a11037p914-918-2016

46. Horta WA. Processo de Enfermagem. São Paulo: EPU, 1979.

47. Oliveira JGC, Almeida EC, Azevedo NM, Almeida Maria AP. Reflexões sobre as bases científicas e fundamentação legal para aplicação da sistematização do cuidado de enfermagem. Rev UNIABEU [Internet]. 2015 [cited 2020 Jul 28];8(20):350-62. Available from: http://revista. uniabeu.edu.br/index.php/RU/artic le/view/1912/pdf_298

48. Dadgari A, Hojati $\mathrm{H}$, Mirrezaie SM. The relationship between the risk of falling and fear of falling among aged, hospitalized patients. Nurs Pract Today. 2020;7(1):30-37. https://doi.org/10.18502/npt.v7i1.2297

49. Staggs VS, Davidson J, Dunton N, Crosser B. Challenges in defining and categorizing falls on diverse unit types: lessons from expansion of the NDNQI Falls Indicator. J Nurs Care Qual. 2015;30(2):106-12. https://doi.org/10.1097/NCQ.0000000000000085 